\title{
Overexpression of an isoform of $A M L 1$ in acute leukemia and its potential role in leukemogenesis
}

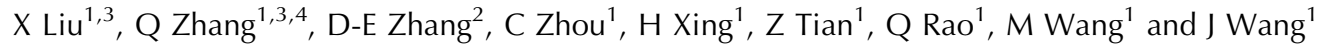 \\ ${ }^{1}$ State Key Laboratory of Experimental Hematology, Institute of Hematology and Blood Diseases Hospital, Chinese Academy of \\ Medical Sciences and Peking Union Medical College, Tianjin, P.R. China and ${ }^{2}$ Department of pathology, University of California \\ San Diego, La Jolla, CA, USA
}

\begin{abstract}
AML1/RUNX1 is a critical transcription factor in hematopoietic cell differentiation and proliferation. From the $A M L 1$ gene, at least three isoforms, $A M L 1 a, A M L 1 b$ and $A M L 1 c$, are produced through alternative splicing. AML1a interferes with the function of AML1b/1c, which are often called AML1. In this study, we found a higher expression level of $A M L 1 a$ in acute lymphoblastic leukemia and acute myeloid leukemia (AML)-M2 patients in comparison to the controls. Additionally, AML1a represses transcription of promoter of macrophage colony-stimulating factor receptor mediated by $A M L 1 b$, indicating that AML1a antagonized the effect of AML1b. To investigate the role of $A M L 1 a$ in hematopoiesis and leukemogenesis in vivo, murine bone marrow mononuclear cells were transduced with $A M L 1 a$ and then transplanted into lethally irradiated mice, which developed lymphoblastic leukemia after transplantation. Taken together, these results indicate that overexpression of $A M L 1 a$ may be an important contributing factor to leukemogenesis. Leukemia (2009) 23, 739-745; doi:10.1038/leu.2008.350;
\end{abstract}

published online 8 January 2009

Keywords: AML1; isoform; M-CSFR; RT-PCR; transactivation; leukemia

\section{Introduction}

AML1, also known as RUNX1, PEBP2 $\alpha B$ or $C B F \alpha 2$, is a transcription factor that plays a crucial role in the proliferation and differentiation of hematopoietic cells. AML1 has a DNA binding domain, known as the runt homology domain (RHD), and a transactivation domain that binds to and regulates target genes, respectively. ${ }^{1}$ AML1 are affected by chromosomal translocations found in human leukemia, including $t(8 ; 21)$, $\mathrm{t}(3 ; 21)$ and $\mathrm{t}(12 ; 21) .^{2-4}$ The $\mathrm{t}(8 ; 21)$ is most frequent chromosomal translocation in acute myeloid leukemia (AML), and it joins AML1 to ETO, resulting in the formation of AML1-ETO fusion gene in which AML1 retains RHD, but lacks the transactivation domain. ${ }^{5,6}$ The lack of transactivational domain is supposed to be the event that triggers leukemogenesis. ${ }^{6}$

AML1 is essential for hematopoiesis in early development as well as in adulthood. AML1-null embryos die typically around E12.5 because of a lack of fetal liver hematopoiesis and hemorrhage in the central nervous system. ${ }^{7,8}$ Loss of $A M L 1$

Correspondence: Professor J Wang, State Key Laboratory of Experimental Hematology, Institute of Hematology and Blood Disease Hospital, Chinese Academy of Medical Sciences and Peking Union Medical College, 288 Nanjing Road, Tianjin 300020, P.R. China.

E-mail: wangjx@ihcams.ac.cn

${ }^{3}$ These authors contributed equally to this work.

${ }^{4}$ Current address: Guangdong No. 2 Provincial People's Hospital Guangzhou 510010, P.R. China.

Received 31 May 2008; revised 30 October 2008; accepted 17 November 2008; published online 8 January 2009 function in adulthood leads to a number of disturbance in hematopoiesis, including retarded megakaryocytic maturation and impaired T- and B-lymphocytic differentiation. ${ }^{9}$ In addition, it has been proved that $A M L 1$-deficient cells are susceptible to malignant transformation. ${ }^{10}$

AML1 regulates promoters or enhancers of many target genes, including interleukin $3,{ }^{11}$ myeloperoxidase, ${ }^{12}$ neutrophil elastase, $^{13}$ granulocyte-macrophage colony-stimulating factor (GM-CSF) ${ }^{14}$ macrophage colony-stimulating factor receptor $(\mathrm{M}-\mathrm{CSFR})^{15,16}$ and T-cell antigen receptor subunits (TCRs). ${ }^{5,17}$ RHD is near the $\mathrm{N}$ terminus and contains approximately 128 amino-acid residues. ${ }^{18,19}$ Affinity of AML1 for its target DNA sequences increases significantly upon heterodimerization with $\mathrm{CBF} \beta .^{20-22}$

At least three alternative splice variants of the $A M L 1$ gene ( $A M L 1 a, A M L 1 b$ and $A M L 1 c$ ) have been identified to date. ${ }^{1}$ The proteins encoded by $A M L 1 b$ and $A M L 1 c$ have an RHD in the $\mathrm{N}$ terminus and a transactivation domain in the $\mathrm{C}$ terminus. ${ }^{1}$ In contrast, the protein encoded by $A M L 1$ a has a RHD but lacks the transactivation domain. As such, the function of AML1 is believed to be mediated by AML1b and AML1C which are considered to have the same function. ${ }^{1}$ Experiments using transient transfection have demonstrated that AML1b, but not AML1a, transactivated TCRs ${ }^{5,17}$ and GM-CSF. ${ }^{23}$ AML1a has no transactivational function by itself, but inhibits the transcriptional activity of AML1b by competing for the DNA sequence of target genes with a higher affinity. ${ }^{6}$ Overexpression of AML1a inhibits the myeloid terminal differentiation of the myeloid precursor lineage 32Dcl3 induced by G-CSF. Recent evidence showed that the overexpressed AML1a is higher in patients with AML than the normal controls. ${ }^{6}$ Accordingly, we hypothesize that $A M L 1 a$, similar to the leukemia-associated fusion proteins, perturbs the normal function of AML1, and maybe contribute to leukemogenesis.

In this study, we first examined the expression level of $A M L 1 a$ in bone marrow mononuclear cells (BMMNCs) of acute leukemia ( $\mathrm{AL}$ ) patients. Results indicated that $A M L 1$ a expression level in acute lymphoblastic leukemia (ALL) and subgroup of AML (AML-M2) patients was significantly higher than that in healthy donors. We further analyze the effects of $A M L 1 a$ and $A M L 1 b$ on the transactivity by using a luciferase reporter plasmid containing M-CSFR promoter. Result demonstrated that AML1a competes with $A M L 1 b$ to inhibit the transcription of $M$ CSFR. Finally the in vivo effect of $A M L 1 a$ was explored by transplantation of $A M L 1 a$ expressing BMMNCs into lethally irradiated mice. Of 12 mice, 9 developed lymphoid leukemia between 16 and 45 weeks after transplantation. These results demonstrated: (1) AML1a is a functional AML1 'antagonist'; (2) overexpression of $A M L 1$ a may serve as a critical oncogenic event to promote leukemogenesis. 


\section{Materials and methods}

\section{Patients and cell lines}

A total of 77 patients with de novo AL from our hospital and 7 healthy donors were studied after giving informed consent. Diagnosis and classification of the leukemia were made on the basis of Morphology-Immunology-Cytogenetics-Molecular biology typing standard using the French-American-British system. $^{24,25}$ CV-1, NIH 3T3 and 293T cell lines were maintained in Dulbecco's modified Eagle medium supplemented with $10 \%$ fetal bovine serum (FBS). U937 cell line was maintained in RPMI 1640 supplemented with 10\% FBS.

\section{$R N A$ isolation and reverse transcriptase polymerase chain reaction}

Described in the Supplementary Information.

\section{Construction of plasmids}

Described in the Supplementary Information.

\section{Transient luciferase assay}

$\mathrm{CV}$ - 1 cells were seeded in six-well plates at a density of $5 \times 10^{5}$ per well. Transfection was performed by using calcium phosphate-mediated precipitation when cells reached $70 \%$ confluence. The following combinations of plasmids were used: $1.2 \mu \mathrm{g}$ of $\mathrm{pM}$-CSF-R-luc reporter plasmid or pM-CSF-R $(\mathrm{mB})$-luc reporter plasmid with different dosage of pcDNA3-FLAG-AML1a and pCMV5-AML1b and with $1 \mu \mathrm{g}$ of $\beta$-galactosidae plasmids. At $6 \mathrm{~h}$ after transfection, the medium was changed. The cells were harvested at $36 \mathrm{~h}$ after transfection for assays of $\beta$-galactosidase and luciferase activity (Promega, Madison, WI, USA).

Viral production, transduction and transplantation of murine bone marrow and tumor cell transplantation Described in the Supplementary Information.

\section{Southern blot analysis and genomic DNA polymerase chain reaction}

Genomic DNA from spleen cells of the leukemic mice was isolated. Genomic DNA (10 $\mu \mathrm{g})$ was digested with Bg/ll or Xhol, electrophoresed on $1 \%$ agarose gel, transferred onto Hybond $\mathrm{N}+$ membrane (Amersham, Piscataway, NJ, USA), and hybridized with a digoxigenin-dUTP-labeled $0.5 \mathrm{~kb}$ (kilobase) $\mathrm{Ncol}$ fragment corresponding yellow fluorescent protein (YFP) or BamHI-Notl fragment corresponding AML1a as probe. Southern blot analysis was performed with Dig high prime DNA labeling and detection starter kit II (Roche Diagnostics, Mannheim, Germany). The washed membrane was exposed to $X$-ray film. For genomic DNA PCR, $0.2 \mu$ of the DNA was used as a template in a $25 \mu \mathrm{l}$ reaction, with primers $5^{\prime}$-CACTATAGG GAGACCCAAG- $3^{\prime}$ and $5^{\prime}$-CTATTCTATAGTGTCACCT- ${ }^{\prime}$ for the human AML1a gene. The PCR reaction was performed for 30 cycles at $94{ }^{\circ} \mathrm{C}$ for $45 \mathrm{~s}, 54{ }^{\circ} \mathrm{C}$ for $45 \mathrm{~s}$ and $72{ }^{\circ} \mathrm{C}$ for $45 \mathrm{~s}$, followed by $72{ }^{\circ} \mathrm{C}$ for $2 \mathrm{~min}$.

\section{Western blot analysis}

We performed protein lysate preparation and western blotting as previously described. ${ }^{26}$ Anti-FLAG monoclonal antibody and anti- $\beta$-actin antibody were purchased from Sigma. The blots were visualized by chemiluminescence (ECL; Amersham, Freiburg, Germany).

\section{Flow cytometry of mouse cells}

For lineage marker analysis, cells $\left(1 \times 10^{6}\right)$ were incubated with monoclonal antibodies against Sca-1, c-Kit, Gr-1, Mac-1, Ter119, B220, CD19, Thy1.2, CD3, CD4, CD8 or their isotype controls (Biolegend, San Diego, CA, USA). The cells were then washed and applied for analysis on a FACSCalibur flow cytometer (Becton Dickinson, San Jose, CA, USA).

\section{Hematological and histological analysis}

Peripheral blood (PB) smears and bone marrow (BM) cytospin slides were stained with Wright-Giemsa staining solution. Tissue samples were fixed with $10 \%$ phosphate-buffered formalin and embedded in paraffin. Sections were stained with hematoxylin and eosin and observed under a light microscope.

\section{Statistical methods}

For statistical analysis, survival curves were produced using the Kaplan-Meier estimates, group distributions were compared parametrically using the Student's $t$-test and group distributions were compared non-parametrically using the Mann-Whitney $U$-test or $\chi^{2}$-test.

\section{Results}

Expression of AML1 isoform in $A L$

BM samples from 77 de novo AL patients, including 51 of $\mathrm{AML}$, 21 of ALL and 5 of biphenotypic acute leukemia (BAL), and 7 healthy donors were analyzed by semiquantitative reverse transcriptase-PCR (RT-PCR). AML1a expression in AL cells is not associated with gender, age, initial white blood cell count and median percentage of BM blast cells (Supplementary Table 1). Expression level of AML1a in 21 ALL patients was significantly higher than that of the healthy controls $(P<0.05$; Figure 1a). However, the expression of $A M L 1 a$ in the healthy controls did not differ significantly from that in AML or BAL (Figure 1a). Furthermore, we analyzed the expression levels of $A M L 1 a$ in different subtypes of AML cases according to FAB phenotype. The result showed that the expression level of $A M L 1 a$ did elevate significantly in $M 2$ patients without $t(8 ; 21)$ translocation compared with that of the healthy controls $(P<0.05$; Figure $1 \mathrm{~b})$. However, there was no significant difference was observed in AML1a expression level between other subtypes of $\mathrm{AML}$ and healthy control. The data suggest that overexpression of AML1a might play an important role in leukemogenesis.

\section{Effects of AML1 transcripts on the transactivation} of M-CSFR gene

As AML1 is a transcription factor and AML1a is overexpressed in ALL and AML-M2 patients, next we analyzed the effects of AML1a on transcription of AML1 target gene. The CV-1 cells were transfected with a plasmid expressing AML1a or AML1b. At $36 \mathrm{~h}$ after transfection, activity of the luciferase reporter gene was analyzed by luminometer. As shown in Figure 2, the transcriptional activity of M-CSFR promoter was activated by AML1b (Figure 2a) in a dose-dependant manner, but not by AML 1a (Figure 2b). A 3.8-fold increase in luciferase activity was observed in cells transfected with pCMV5-AML1b at a dose of $0.2 \mu \mathrm{g}$, but not in cells transfected with pcDNA3-FLAG-AML1a 
a

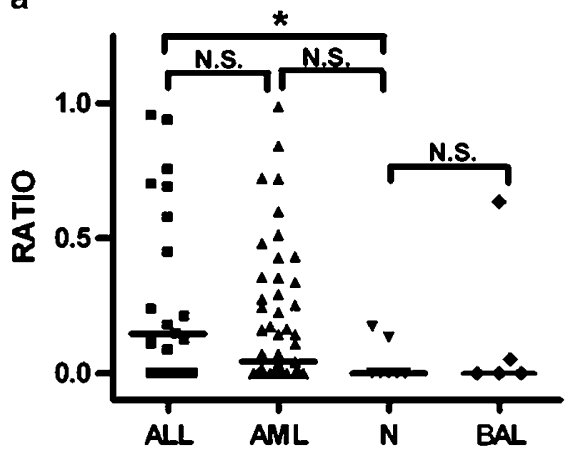

b

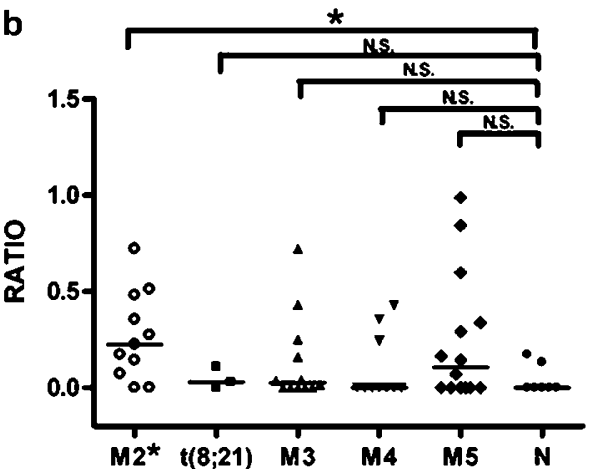

Figure 1 Expression of $A M L 1$ a gene in acute leukemia and healthy donors. (a) Expression of $A M L 1$ a gene in bone marrow mononuclear cells (BMMNC) of patients with acute lymphoblastic leukemia (ALL), acute myeloid leukemia (AML), biphenotypic acute leukemia (BAL) and healthy donors. There was a significant difference between ALL patients and healthy donors. (b) Expression of AML1a gene in BMMNC of patients with different subtypes of AML and healthy donors. There was a significant difference between AML-M2 patients without $\mathrm{t}(8 ; 21)$ and healthy donors. M2*, AML-M2 without $\mathrm{t}(8 ; 21)$ translocation; $\mathrm{t}(8 ; 21)$, AML-M2 with $\mathrm{t}(8 ; 21)$ translocation; ' ${ }^{\prime}$ ' shows median value; ${ }^{*} P<0.05$; NS, not significant.

a

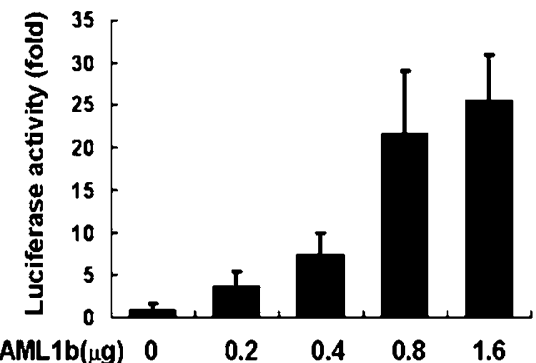

C

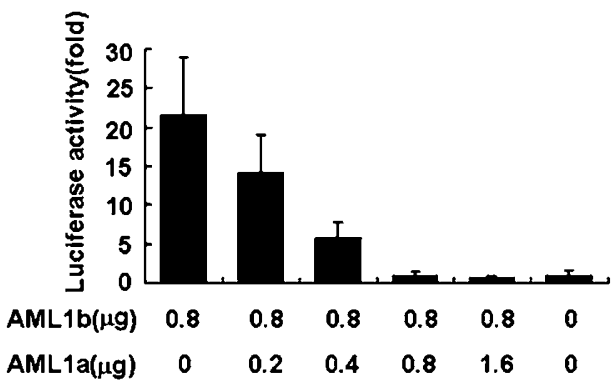

b

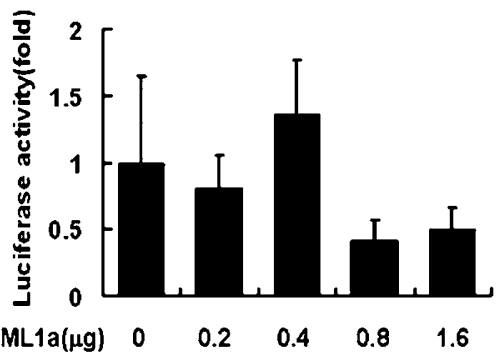

d

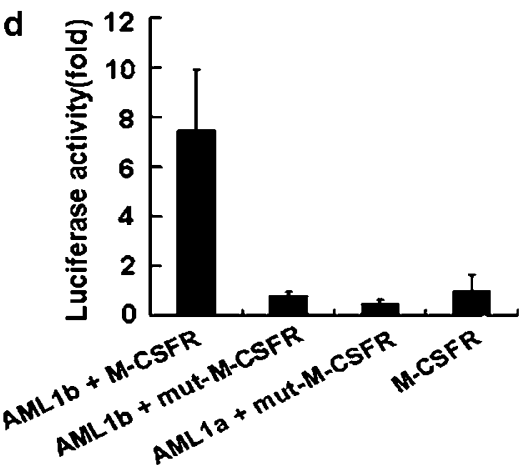

Figure 2 Effects of $A M L 1$ transcripts on the transactivation of macrophage colony-stimulating factor receptor (M-CSFR) gene promoter. (a) Transactivity of $A M L 1 b$ alone at different dosages. (b) Transactivity of $A M L 1 a$ alone at different dosages. (c) Abrogation of $A M L 1 b$ transactivity by AML1a in a dose-dependent manner. (d) Effect of AML1 binding site mutation of M-CSFR promoter on transactivity. Error bars: standard error of the mean.

at the same dose (Figures $2 \mathrm{a}$ and $\mathrm{b})$. The difference between the two isoforms was statistically significant $(P<0.01)$. As shown in Figure 2c, transactivation of M-CSFR mediated by AML1b was abrogated by cotransfection with AML1a in a dose-dependent manner. The aforementioned effects were completely absent in cells with mutant M-CSFR promoter in which AML1 binding sequence was disrupted (Figure $2 \mathrm{~d}$ ), indicating the specificity of the findings.

\section{AML1a induces the development of lymphoblastic} leukemia

As AML1a could interfere the transcription regulation mediated by full length of AML1, AML1b. Overexpression of $A M L 1 a$ in hematopoietic cells may result in impairment of hematopoiesis or development of leukemia. To address this issue, we analyzed the effects of AML1a in vivo. BMMNCs infected with the retroviral vector murine stem cell virus (MSCV) expressing a FLAG-AML1a fusion protein and a YFP (Figure 3a) were inoculated into the lethally irradiated female $\mathrm{C} 57 \mathrm{BL} / 6 \mathrm{~J}$ mice. BMMNCs infected with the vector expressing YFP only were used as control. Number of transplanted YFP-positive cells in both groups was approximately 30000 per mouse. The expression of the fusion proteins was confirmed by western blot (data not shown). Number of YFP-positive cells in PB as well as general health condition of the mice was surveyed closely. Of the 12 mice in the AML1a group, 9 developed leukemia at 3-11 months (Figure 3b; Table 1). Signs of cachexia, 
a

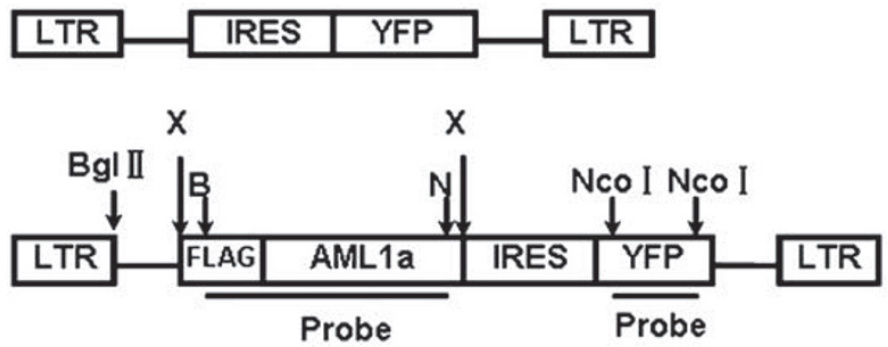

b

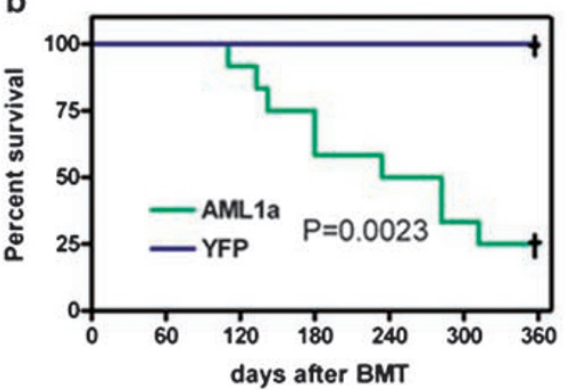

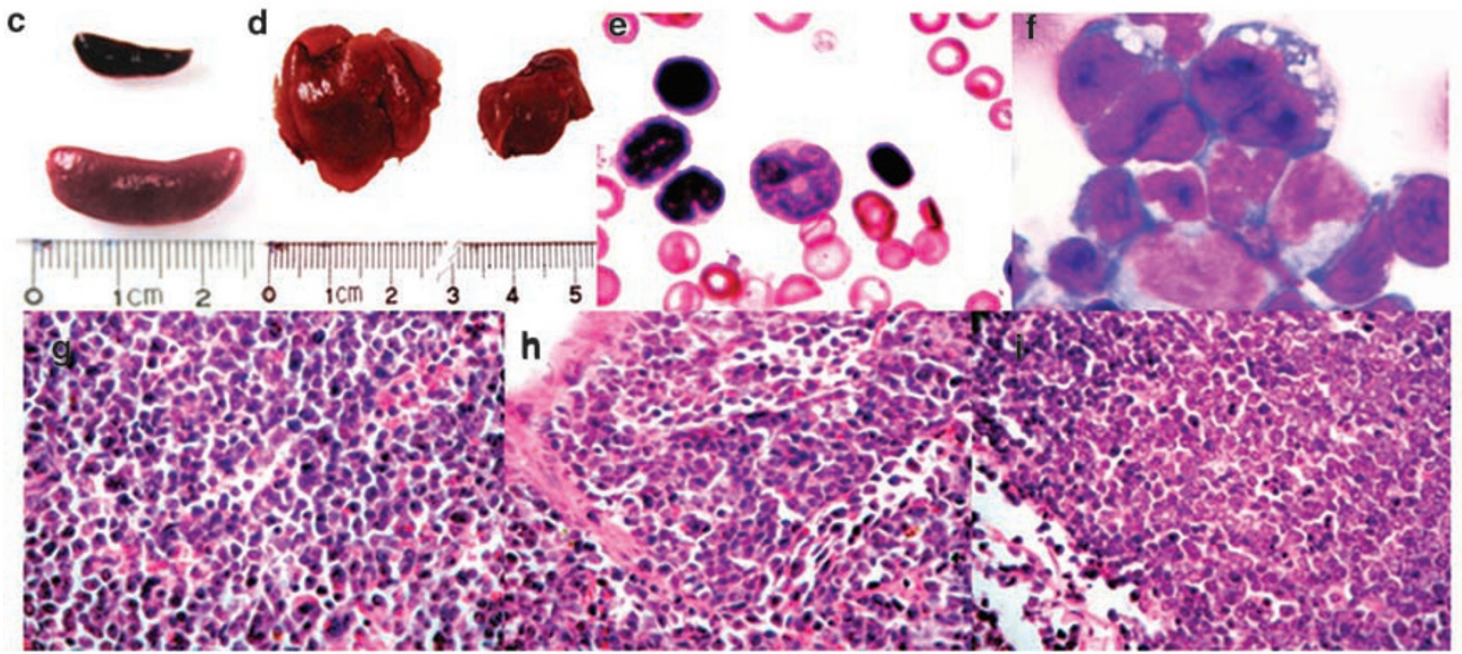

Figure 3 Gross and histopathology of AML1a mice with leukemia phenotype. (a) The structure of retroviral plasmids: pMSCV-IRES-YFP and pMSCV-FLAG-AML1a-IRES-YFP. Positions of restriction enzyme sites as well as probe used for Southern blot are indicated. X, Xhol; N, Notl; B BamHI. (b) Kaplan-Meier survival curves (leukemia free) of recipient mice transduced with either AML1a $(n=12)$ or a vector control $(n=12)$. Autopsy of these animals revealed: splenomegaly (the upper panel is the control spleen; c), hepatomegaly (d) the right panel is the control liver). Wright-Giemsa-stained peripheral blood (PB) $(\mathbf{e})$ and bone marrow (BM) $(\mathbf{f})$ cytospin from representative leukemic AML1a mice $(\times 1000)$ and hematoxylin and eosin $(\mathrm{H} \& \mathrm{E})$ staining of involved organs $(\mathbf{g}-\mathbf{i})(\times 400)$. The normal framework was destroyed and infiltrated by large number of tumor cells in BM (g), spleen (h) and thymus (i).

Table 1 Characteristics of AML1a-induced leukemia mice

\begin{tabular}{|c|c|c|c|c|c|c|c|c|c|}
\hline No. mice & 101 & 102 & 103 & 105 & 108 & 110 & 107 & 109 & 111 \\
\hline $\begin{array}{l}\text { Survival time after BMT (days) } \\
\text { Phenotypes of BM and SP }\end{array}$ & $\begin{array}{l}110 \\
\text { ND }\end{array}$ & $\begin{array}{l}133 \\
N D\end{array}$ & $\begin{array}{c}142 \\
\text { Sca-1 } \\
\text { cCD3 }\end{array}$ & $\begin{array}{c}180 \\
\text { Sca-1 } \\
\text { cCD3 }\end{array}$ & $\begin{array}{c}180 \\
\text { Sca-1 } \\
\text { cCD3 }\end{array}$ & $\begin{array}{l}234 \\
\text { Sca-1 } \\
\text { c-Kit } \\
\text { Thy1.2 } \\
\text { CD3 } \\
\text { CD4 } \\
\text { CD8 }\end{array}$ & $\begin{array}{l}282 \\
\text { Thy1.2 } \\
\text { CD3 } \\
\text { CD4 } \\
\text { CD8 }\end{array}$ & $\begin{array}{l}282 \\
\text { Sca-1 } \\
\text { c-Kit } \\
\text { Thy1.2 } \\
\text { CD3 } \\
\text { CD4 } \\
\text { CD8 }\end{array}$ & $\begin{array}{l}312 \\
\text { Sca-1 } \\
\text { c-Kit } \\
\text { Thy1.2 } \\
\text { CD3 } \\
\text { CD4 } \\
\text { CD8 }\end{array}$ \\
\hline $\begin{array}{l}\text { Thymoma } \\
\text { SP weight (g) }\end{array}$ & $\begin{array}{l}\text { ND } \\
\text { ND }\end{array}$ & $\begin{array}{l}\text { ND } \\
\text { ND }\end{array}$ & $\stackrel{+}{0.2}$ & $\begin{array}{c}- \\
0.4\end{array}$ & $\stackrel{+}{0.2}$ & $0 . \overline{31}$ & $\stackrel{+}{0.2}$ & $\stackrel{+}{0.21}$ & $\stackrel{+}{0.42}$ \\
\hline WBC $\left(\times 10^{6}\right.$ per $\left.\mathrm{ml}\right)$ & 10.1 & 12.7 & 15.2 & 12.7 & 12 & 15.2 & 22.6 & 23.4 & 30.2 \\
\hline Diagnosis & ALL & ALL & T-ALL & T-ALL & T-ALL & T-ALL & T-ALL & T-ALL & T-ALL \\
\hline
\end{tabular}

Abbreviations: BM, bone marrow; ND, not determined; SP, spleen.

such as loss of body weight in these mice coincided with a rapid rise of YFP-positive cells from an initial level of $2-3 \%$ to $10-25 \%$ in $\mathrm{PB}$. The median survival time of the mice in the AML1a group was 258 days. Autopsy of these mice revealed splenomegaly and hepatomegaly (Figures $3 \mathrm{c}$ and d), sometimes with thymoma and lymph node enlargement. BM, spleen, lung, liver, kidney and thymus were infiltrated with leukemia cells (Figures 3e-i).
A Southern blot analysis by using digoxigenin-dUTP-labeled YFP probe showed that most of the integration of AML1a retrovirus in leukemic cells was monoclonal (Figures 3a and 4a). Genomic PCR and Southern blot analysis by using digoxigenindUTP-labeled AML1a probe were performed to verify the integration of $A M L 1 a$ in the genome of leukemic spleen cells (Figures 3a, 4a and b). RT-PCR was performed to analyze the expression of $A M L 1 a$ in spleen cells of mice (Figure 4c). The 

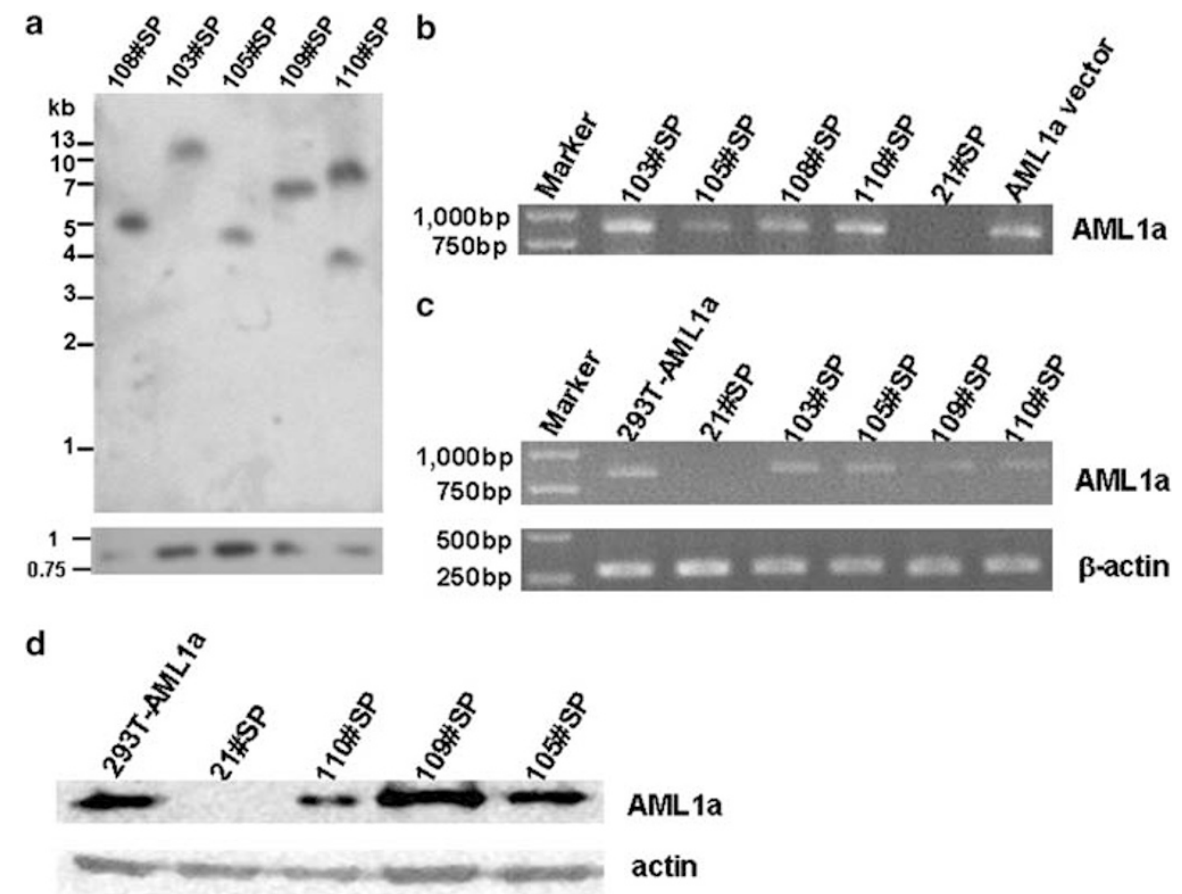

Figure 4 Integration and expression of AML1a in spleen cells of leukemic mice. (a) Southern blot analysis of MSCV-FLAG-AML1a-IRES-YFP proviral integration in AML1a transduced mice. DNA was digested with Bg/lI, which cuts once in the proviral sequence, and blots were hybridized to a yellow fluorescent protein (YFP) probe (top). DNA was digested with Xhol, which cuts twice in the proviral sequence, and blots were hybridized to a AML1 a probe (bottom). (b) Genomic DNA specific for AML1a in isolated leukemia cells as detected by genomic PCR. As a positive control, a plasmid containing AML1a template was amplified. SP, spleen. (c) RNA was isolated from the spleen. Cells were transduced with either $A M L 1$ a or YFP only. Expression of $\beta$-actin (bottom). M, marker. (d) Western blot analysis of FLAG (AML1a) protein from the spleen of the mice. 293 T cells transduced with AML1a served as a positive control. Spleen cells in mouse $21 \#$ transduced with YFP only were included as a negative control. $\beta$-Actin was used as a loading control.

293 T cells transfected with plasmid pMSCV-FLAG-AML1aIRES-YFP was used as a positive control. As indicated in Figure $4 \mathrm{~d}$, the FLAG-AML1a fusion protein was clearly detected in the spleen sample of the AML1a leukemic mice.

Flow cytometry showed that $30-60 \%$ of the BMMNCs from AML 1 a group were positive for YFP, in comparison to $8-15 \%$ in the control group. A further analysis revealed that there are two different phenotypes of T-lymphoblastic leukemia in mice with leukemia (Table 1 ). One was Sca- ${ }^{+}{ }^{+}$, cytoplasmic $\mathrm{CD}^{+}{ }^{+}\left(\mathrm{cCD}^{+}{ }^{+}\right.$; Figure $\left.5 \mathrm{a}\right)$, the other was $\mathrm{CD} 3^{+} \mathrm{CD} 4^{+} \mathrm{CD} 8^{+}$ (Figure 5b).

To assess transplantability of the leukemia, spleen cells from each leukemic mouse were inoculated into four naive mice through the tail vein. All mice rapidly developed lymphoblastic leukemia, with an average latency of 47 days (data not shown).

\section{Discussion}

In this study, we found that $A M L 1 a$ is overexpressed in patients of ALL and AML-M2. A previous study using a qualitative assay for $A M L 1$ a RRNA $^{6}$ showed that AML1a could be detected in half of the patients with $\mathrm{AML}$, whereas almost no expression of AML1a could be detected in normal subjects. Here, we used a semiquantitative assay to expand the investigation in more subjects. Surprisingly, we did not find a significant difference in the expression of $A M L 1$ a between all subtypes $A M L$ patients except AML-M2 and the healthy donors. Instead, a significant difference was found between ALL patients and the control. However, the number of patients and healthy controls was limited in this study, further investigation should be performed to expand the sample number to obtain more accurate expression levels of AML1a in patients.

AML1-ETO, as a dominant negative protein, blocks transactivation of the GM-CSF promoter mediated by AML1b. ${ }^{23}$ AML1-ETO constitutes the first hit by blocking the differentiation of hematopoietic stem cell (HSC). Myeloid leukemia develops when the second hit occurs. ${ }^{26}$ Initially, we suppose that, similar to AML1-ETO, AML1a lacks transcriptional activity, but binds to target genes with higher affinity than $\mathrm{AML} 1 \mathrm{~b},{ }^{6}$ and thus may contribute to leukemogenesis. It would influence myeloid differentiation and play a certain role in development of leukemia, so we choose M-CSFR as the target gene of AML1 to study. In our experiments, activity of the M-CSFR promoter was dose-dependently transactivated by $A M L 1 b$, but not by $A M L 1$ a. More importantly, $A M L 1 a$ interfered with the transactivational effect of $A M L 1 b$ in a dose-dependent manner. A previous study also demonstrated that such an inhibitory effect by $A M L 1 a$ could be reversed by the overexpression of $A M L 1 b$ suggesting a competitive mechanism.

In our experiments in vivo, $75 \%$ of the recipient mice after transplantation of AML1a retrovirus-infected BMMNCs developed leukemia. In comparison with the results in patients, the leukemia cells in these mice were only lymphoblastic, which is in accord with the evidence that AML1 is indeed involved in the regulation of T-cell-specific gene expression. ${ }^{27}$ In addition, the investigation of the AML1 transcription suggests that AML1 may be critically involved in differentiation of lymphoid precursors in adult hematopoiesis. ${ }^{28}$ Moreover, transition of the T cells from the $\mathrm{CD}^{-} \mathrm{CD}^{-}(\mathrm{DN})$ to the $\mathrm{CD} 4{ }^{+} \mathrm{CD} 8{ }^{+}$(DP) phenotype is impaired in transgenic mice bearing a truncated, dominant interfering form of AML1 (runt). ${ }^{29}$ Consistent with the findings by 
a

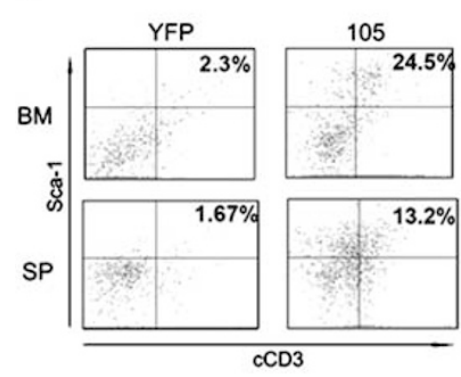

b

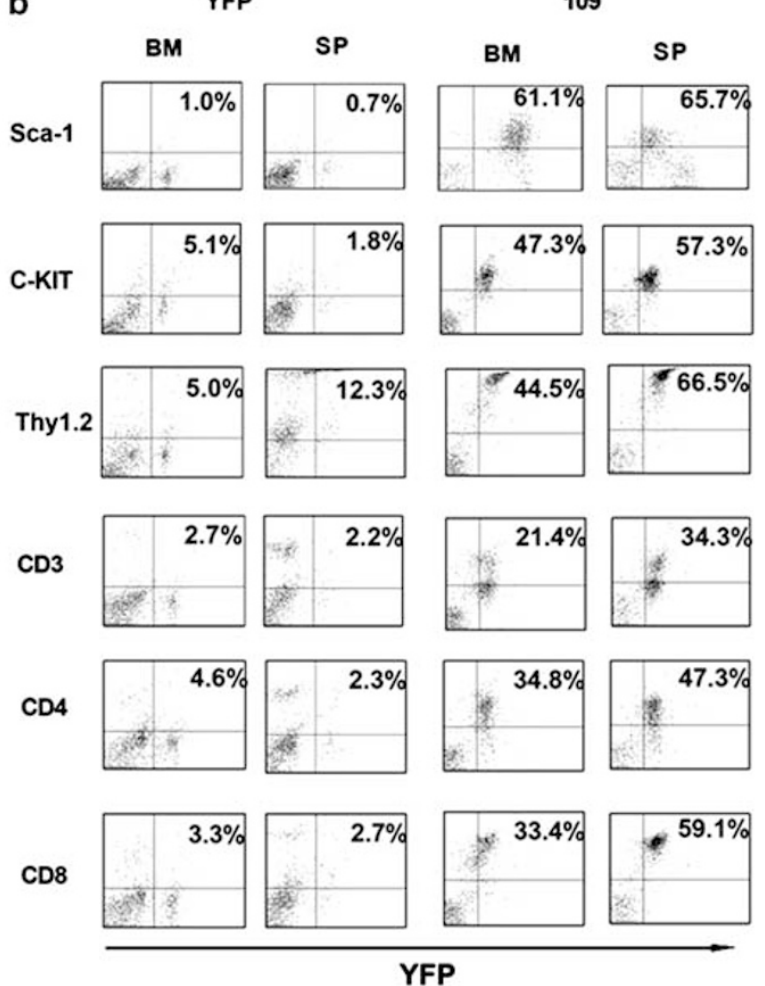

Figure 5 Flow-cytometric analysis of mononuclear cells from bone marrow (BM) and spleen (SP) of AML1a mice with leukemia phenotype. (a) Increased $\mathrm{Sca}-1^{+} / \mathrm{CCD}^{+}$cell populations in the $\mathrm{YFP}^{+}$cells of $\mathrm{BM}$ and spleen from a representative AML1a leukemic mouse (105\#) phenotype as compared to those in the $\mathrm{YFP}^{+}$cells of BM and SP from a control animal. (b) Flow cytometry analysis on BM cells and spleen cells freshly isolated from an AML1a leukemia mouse (109\#) with a T-lymphoblastic leukemia phenotype, and a control mouse. The plots showed expression of lineage-specific antigens (Sca-1, c-Kit, Thy1.2, CD3, CD4, CD8) versus yellow fluorescent protein (YFP). Numbers indicated the percentage of cells in the quadrant.

Sato et al., ${ }^{30}$ we found that overexpression of AML1a may also influence DN or DP phase of T cells. Finally, AML1 deficiency has been reported to predispose mice to T-lymphoblastic lymphoma. ${ }^{10}$

Our data suggest that $A M L 1$ a overexpression may be a critical event in the development of leukemia. However, the overexpression of AML1a alone may not be sufficient for leukemogenesis. First, not all AML1a-transduced mice developed leukemia. Second, leukemia developed after a relatively long period, suggesting that additional mutations or hits may be required. The monoclonal integration of AML1a retrovirus in leukemic cells may also support this hypothesis. Two different immunophenotypes of lymphoid leukemia were observed in leukemic mice, indicating that some mutations occurred in different development and differentiation stages of HSC. A recent study by Tsuzuki et al. suggested that AML1a may enhance the self-renewal capacity of HSC. Based on the findings that the overexpression of AML1a increases the engraftment potential of hematopoietic stem and progenitor cells, it is suggested that AML1a may be applied in hematopoietic cell transplantation to expand the number of cells. ${ }^{31}$ However, results from this study provided experimental evidence that the safety to utilize AML1a in transplantation was called in question before a thorough investigation.

In conclusion, our study indicated that AML1a may play a critical role in leukemogenesis, especially in the development of lymphoid leukemia. In addition, lymphoblastic leukemia model established in this study may serve as a valuable tool for future studies.

\section{Acknowledgements}

We are grateful to Hongguang Ying (State Key Laboratory of Experimental Hematology, China) for histological analysis. We thank Prof Misao Ohki (Saitama Cancer Center Research Institute, Japan) and Dr Hiebert (St Jude Children's Hospital, USA) for providing pBlue-script II KS $(+)$ plasmid containing AML1a cDNA and PCMV5-AML1b plasmid, respectively. This work was supported by Major State Basic Research Development Program (2006CB910406) and National Natural Science Fund (30871096) of China.

\section{References}

1 Miyoshi H, Ohira M, Shimizu K, Mitani K, Hirai H, Imai T et al. Alternative splicing and genomic structure of the AML1 gene involved in acute myeloid leukemia. Nucleic Acids Res 1995; 23: 2762-2769.

2 Miyoshi H, Shimizu K, Kozu T, Maseki N, Kaneko Y, Ohki M. $\mathrm{t}(8 ; 21)$ breakpoints on chromosome 21 in acute myeloid leukemia are clustered within a limited region of a single gene, AMLI. Proc Natl Acad Sci USA 1991; 88: 10431-10434.

3 Nucifora G, Birn DJ, Espinosa R, Erickson P, LeBeau MM, Roulston $\mathrm{D}$ et al. Involvement of the AML1 gene in therapy-related leukemia and in chronic myeloid leukemia in blast crisis. Blood 1993; 81: 2728-2734.

4 Golub TR, Barker GF, Bohlander SK, Hiebert SW, Ward DC, Bray-Ward P et al. Fusion of the Tel gene on 12p13 to the AML1 on $21 \mathrm{q} 22$ in acute lymphoblastic leukemia. Proc Natl Acad Sci USA 1995; 92: 4917-4921. 
5 Meyers S, Lenny $\mathrm{N}$, Hiebert SW. The $\mathrm{t}(8 ; 21)$ fusion protein interferes with AML-1B-dependent transcnptional activation. Mol cell Biol 1995; 15: 1974-1982.

6 Tanaka T, Tanaka K, Ogawa S, Kurokawa M, Mitani K, Nishida J et al. An acute myeloid leukemia gene, AML1, regulates hemopoietic myeloid cell differentiation and transcriptional activation antagonistically by two alternative spliced forms. $E M B O$ J 1995; 14: 341-350.

7 Okuda T, van Deursen J, Hiebert SW, Grosveld G, Downing JR. AML1, the target of multiple chromosomal translocations in human leukemia, is essential for normal fetal liver hematopoiesis. Cell 1996; 84: 321-330.

8 Wang Q, Stacy T, Binder M, Marín-Padilla M, Sharpe $A H$ Speck NA. Disruption of the Cbfa2 gene causes necrosis and hemorrhaging in the central nervous system and blocks definitive hematopoiesis. Proc Natl Acad Sci USA 1996; 93: 3444-3449.

9 Ichikawa M, Asai T, Saito T, Seo S, Yamazaki I, Yamagata T et al. AML-1 is required for megakaryocytic maturation and lymphocytic differentiation, but not for maintenance of hematopoietic stem cells in adult hematopoiesis. Nat Med 2004; 10: 299-304.

10 Kundu M, Compton S, Garrett-Beal L, Stacy T, Starost MF, Eckhaus $\mathrm{M}$ et al. Runx1 deficiency predisposes mice to T-lymphoblastic lymphoma. Blood 2005; 106: 3621-3624.

11 Uchida H, Zhang J, Nimer SD. AML1A and AML1B can transactivate the human IL-3 promoter. J Immunol 1997; 158: 2251-2258.

12 Britos-Bray M, Friedman AD. Core binding factor cannot synergistically activate the myeloperoxidase proximal enhancer in immature myeloid cells without c-Myb. Mol Cell Biol 1997; 17: 5127-5135.

13 Nuchprayoon I, Meyers S, Scott LM, Suzow J, Hiebert S, Friedman AD. PEBP2/CBF, the murine homolog of the human myeloid AML1 and $\mathrm{PEBP} 2 \mathrm{~b} / \mathrm{CBFb}$ proto-oncoproteins, regulates the murine myeloperoxidase and neutrophil elastase genes in immature myeloid cells. Mol Cell Biol 1994; 14: 5558-5568.

14 Cockerill PN, Osborne CS, Bert AG, Grotto RJ. Regulation of GMCSF gene transcription by core-binding factor. Cell Growth Differ 1996; 7: 917-922.

15 Rhoades KL, Hetherington CJ, Rowley JD, Hiebert SW, Nucifora G, Tenen DG et al. Synergistic up-regulation of the myeloid-specific promoter for the macrophage colony-stimulating factor receptor by AML1 and the $t(8 ; 21)$ fusion protein may contribute to leukemogenesis. Proc Natl Acad Sci USA 1996; 93 11895-11900.

16 Zhang DE, Hetherington Cl, Meyers S, Rhoades KL, Larson CJ, Chen HM et al. CCAAT enhancer-binding protein (C/EBP) and AML1 (CBF alpha2) synergistically activate the macrophage colony-stimulating factor receptor promoter. Mol Cell Biol 1996 ; 16: $1231-1240$.
17 Fujii M, Hayashi K, Niki M, Chiba N, Meguro K, Endo K et al. Overexpression of AML1 renders a T hybridoma resistant to $\mathrm{T}$ cell receptor mediated apoptosis. Oncogene 1998; 17: 1813-1820.

18 Daga A, Tighe JE, Calabi F. Leukaemia/Drosophila homology. Nature 1992; 356: 484.

19 Kagoshima H, Shigesada K, Satake M, Ito $Y$, Miyoshi H, Ohki M et al. The runt domain identifies a new family of heteromeric transcriptional regulators. Trends Genet 1993; 9: 338-341.

20 Meyers S, Downing JR, Hiebert SW. Identification of AML-1 and the $(8 ; 21)$ translocation protein $(\mathrm{AML}-1 / \mathrm{ETO})$ as sequence specific DNA binding proteins: the runt homology domain is required for DNA binding and protein-protein interactions. Mol Cell Biol 1993; 13: 6336-6345.

21 Wang S, Wang Q, Crute BE, Melnikova IN, Keller SR, Speck NA. Cloning and characterization of subunits of the T-cell receptor and murine leukemia virus enhancer core-binding factor. Mol Cell Biol 1993; 13: 3324-3339.

22 Ogawa E, Inuzuka M, Maruyama M, Satake M, Naito-Fujimoto M, Ito $\mathrm{Y}$ et al. Molecular cloning and characterization of PEBP2b, the heterodimeric partner of a novel Drosophila runt-related DNA binding protein PEBP2. Virology 1993; 194: 314-331.

23 Frank R, Zhang J, Uchida H, Meyers S, Hiebert SW, Nimer SD. The AML1 /ETO fusion protein blocks transactivation of the GM-CSF promoter by AML1B. Oncogene 1995; 11: 2667-2674.

24 Bennett JM, Catovsky D, Daniel MT, Flandrin G, Galton DA, Gealnick HR et al. Proposals for the classification of the acute leukaemias. French-American-British (FAB) co-operative group. $\mathrm{Br}$ J Haematol 1976; 33: 451-458.

25 Lo Coco F, Foa R. Diagnostic and prognostic advances in the immunophenotypic and genetic characterization of acute leukaemia. Eur J Haematol 1995; 55: 1-9.

26 Zhang X, Diao S, Rao Q, Xing H, Liu H, Liao X et al. Identification of a novel isoform of iASPP and its interaction with p53. J Mol Biol 2007; 368: 1162-1171.

27 Fenske TS, Pengue G, Mathews V, Hanson PT, Hamm SE, Riaz N et al. Stem cell expression of the AML1/ETO fusion protein induces a myeloproliferative disorder in mice. Proc Natl Acad Sci USA 2004; 101: 15184-15189.

28 Ogawa E, Maruyama M, Kagoshima H, Inuzuka M, Lu J, Satake M et al. PEBP2/PEA2 represents a family of transcription factors homologous to the products of the Drosophila runt gene and the human AML1 gene. Proc Natl Acad Sci USA 1993; 90: 6859-6863.

29 Bäsecke J, Feuring-Buske M, Brittinger G, Schaefer UW, Hiddemann W, Griesinger F. Transcription of AML1 in hematopoietic subfractions of normal adults. Ann Hematol 2002; 81: 254-257.

30 Sato T, Ito R, Nunomura S, Ohno S, Hayashi K, Satake M et al. Requirement of transcription factor $\mathrm{AML1}$ in proliferation of developing thymocytes. Immunol Lett 2003; 89: 39-46.

31 Tsuzuki S, Hong D, Gupta R, Matsuo K, Seto M, Enver T. Isoformspecific potentiation of stem and progenitor cell engraftment by AML1/RUNX1. PLoS Med 2007; 4: e172.

Supplementary Information accompanies the paper on the Leukemia website (http://www.nature.com/leu) 